BMJ Open

Sport \&

Exercise

Medicine

\title{
No standarisation or harmonisation in anti-doping testing frequency
}

\section{Bill Cuddihy}

To cite: Cuddihy B. No standarisation or harmonisation in anti-doping testing frequency. BMJ Open Sport \& Exercise Medicine 2020;0: e000739. doi:10.1136/ bmjsem-2020-000793

- Supplemental material is published online only. To view please visit the journal online (http://dx.doi.org/10.1136/ bmjsem-2020-000793).

Received 31 March 2020 Revised 10 August 2020 Accepted 6 September 2020

Check for updates

(c) Author(s) (or their employer(s)) 2020. Re-use permitted under CC BY-NC. No commercial re-use. See rights and permissions. Published by BMJ.

Royal College of Surgeons in Ireland Faculty of Sports and Exercise Medicine, Dublin, Ireland

Correspondence to Bill Cuddihy; billcuddihy@hotmail.com

\section{ABSTRACT}

The use of performance-enhancing drugs (PEDs) has undermined the credibility of sports for many years, with cycling and athletics, especially badly hit. The World Anti-Doping Agency has been tasked with leading the fight against the use of PEDs in sport and has been largely successful in achieving standardisation and harmonisation in terms of rules and regulations but has not addressed the question of testing frequency to any meaningful extent. This study, which focuses on athletics, shows vast differences in testing rates around the world with some of the most successful countries in athletics doing very little testing compared to many other countries.

\section{OVERVIEW OF TESTING RATES}

The next version of the World Anti-Doping Agency (WADA) Code, due to be implemented next year (2021), will, like its predecessors, include a commitment to standardisation and harmonisation.

The Code is the core document that brings consistency to anti-doping worldwide. The Code harmonises anti-doping policies, rules and regulations, and sets the standards which aim to foster consistency among anti-doping organisations in various areas.

One aspect of standardisation and harmonisation that has not received much attention from WADA is the frequency of anti-doping testing in different countries.

Online supplemental table 1 shows the number of all anti-doping tests, urine and various types of blood tests, both incompetition (IC) and out-of-competition (OOC), carried out by National Anti-Doping Organisations (NADOs) in different countries in 2018 as per WADA testing figures released in late December 2019. These testing figures are then divided against the population of each country to give an overall testing rate per million in the population.

The difference in testing rates is very striking. Certain countries with huge financial resources and a very successful sporting history appear to do very little testing. Northern European countries appear to have a very high testing rate.

\section{Key points}

There is no standardisation or harmonisation of antidoping testing frequency.

- Some of the most successful countries in athletics record a low level of testing in comparison to other countries.

- WADA and World Athletics could take this opportunity of a hiatus in activities to review their programmes.

- In many parts of the world, a robust anti-doping testing programme has never been tried.

However, this method of analysis is fairly crude and takes no account of the sporting population within a country as opposed to the total population. Certain countries with very large populations appear to have very small sporting populations. For example, Indonesia, with a population of 267 million has never won a single medal in the 17 editions of the World Athletics Championships. So it would not be reasonable to expect them to have the same testing rate per million in the total population as northern European countries that have a high sporting population.

\section{IC VERSUS OOC TESTS}

The figures in online supplemental table 1 also take no account of the difference in the ratio of IC to OOC testing in different countries.

IC testing is, as the name suggests, testing that takes place at a competition. IC testing is often used by anti-doping organisations to test a variety of levels of athletes to highlight the issue of drugs in sport. OOC testing on the other hand is used almost exclusively for elite athletes (EAs).

IC testing can be said to be relatively predictable and also requires less resources and therefore less costly to operate than a robust OOC testing programme. OOC testing is more costly to operate and more intrusive on the athletes and much less predictable.

Recent work $^{1}$ has shown that fear of increased frequency of testing, particularly 
OOC testing, has a preventive effect on athletes when considering taking performance-enhancing drugs (PEDs). For the remainder of this paper, the author will concentrate on OOC testing.

\section{IDENTIFYING ATHLETICS SPORTING POPULATION}

Identifying and quantifying the sporting population in different countries is not an easy task. For the purposes of this study, the author has concentrated on track and field athletics. The reasons for choosing athletics include the fact that it has a good geographical spread, is open to both genders, is a high-profile Olympic sport and has ongoing issues with the use of PEDs and thus should be subject to robust anti-doping measures.

Using 'Athletics 2019', the Association of Track and Field Statisticians Annual, ${ }^{2}$ the author has identified the top 50 performers in 2018 in each athletic discipline that is included in the Olympic programme. There are 22 events for men and 21 events for women. (There is no $50 \mathrm{~km}$ walk for women.)
Some athletes may appear in the top 50 in more than one event, for example, $100 \mathrm{~m}$ and $200 \mathrm{~m}$, but for the purposes of this study, they are only included once. There are 54 duplications in men and 82 in women leaving 1046 men and 968 women. In this study, these athletes will be referred to as EAs.

In table 1, the second column shows the distribution of EAs in different countries from the most numerous to a level of five EAs. ${ }^{2}$ There is no surprise in the distribution of EAs as it mirrors the success rate in terms of finalists and podium finishers at major championships.

Previous unpublished studies carried out by the author done in 2012 and 2014 show very little difference from these figures with the exception of Russia which had 190 EAs in 2012, 145 EAs in 2014 and 79 EAs in 2018. The reasons for this finding are well known and outside the scope of this paper. Russia is a special case.

It is worth noting that the EA population in many countries corresponds roughly with the actual population of the country.

\begin{tabular}{|c|c|c|c|c|c|c|}
\hline Country & Elite-top 50 & NADO OOC & NADO rate & IAAF OOC & Total OOC & Total rate \\
\hline USA & 338 & 1220 & 3.6 & 890 & 2110 & 6.2 \\
\hline Kenya & 160 & 471 & 2.9 & 1306 & 1777 & 11.1 \\
\hline Germany & 91 & 1748 & 19.2 & 394 & 2142 & 23.5 \\
\hline Ethiopia & 90 & 280 & 3.1 & 635 & 915 & 10.2 \\
\hline Russia & 79 & 1436 & 18.2 & 126 & 1562 & 19.8 \\
\hline UK & 72 & 462 & 6.4 & 225 & 687 & 9.5 \\
\hline Jamaica & 69 & 240 & 3.5 & 62 & 302 & 4.4 \\
\hline China & 67 & 1723 & 25.7 & 199 & 1922 & 28.7 \\
\hline France & 57 & 490 & 8.6 & 118 & 608 & 10.7 \\
\hline Japan & 53 & 394 & 7.4 & 78 & 472 & 8.9 \\
\hline Poland & 44 & 213 & 4.8 & 98 & 311 & 7.1 \\
\hline South Africa & 41 & 186 & 4.2 & 64 & 250 & 6.1 \\
\hline Australia & 38 & 249 & 6.5 & 15 & 264 & 6.9 \\
\hline Spain & 38 & 608 & 16 & 201 & 809 & 21.3 \\
\hline Ukraine & 37 & 281 & 7.6 & 68 & 349 & 9.4 \\
\hline Italy & 36 & 413 & 11.5 & 85 & 498 & 13.8 \\
\hline Canada & 35 & 242 & 6.9 & 20 & 262 & 7.5 \\
\hline Belarus & 33 & 144 & 4.4 & 61 & 205 & 6.2 \\
\hline Brazil & 27 & 11 & 0.4 & 28 & 39 & 1.4 \\
\hline Sweden & 24 & 270 & 11.3 & 14 & 284 & 11.8 \\
\hline Cuba & 23 & 26 & 1.1 & 45 & 71 & 3.1 \\
\hline Netherlands & 21 & 114 & 5.4 & 68 & 182 & 8.7 \\
\hline India & 20 & 259 & 13 & 52 & 311 & 15.5 \\
\hline Czech & 19 & 66 & 3.5 & 104 & 170 & 8.9 \\
\hline Belgium & 17 & 150 & 8.8 & 17 & 167 & 9.8 \\
\hline Morocco & 17 & 52 & 3 & 128 & 180 & 10.6 \\
\hline Turkey & 17 & 493 & 29 & 56 & 549 & 32.3 \\
\hline Greece & 16 & 2 & 0.1 & 29 & 31 & 1.9 \\
\hline Colombia & 16 & 11 & 0.7 & 31 & 42 & 2.6 \\
\hline Norway & 15 & 192 & 12.8 & 26 & 218 & 14.5 \\
\hline Portugal & 15 & 57 & 3.8 & 62 & 119 & 7.9 \\
\hline
\end{tabular}




\begin{tabular}{|c|c|c|c|c|c|c|}
\hline Country & Elite-top 50 & NADO OOC & NADO rate & IAAF OOC & Total OOC & Total rate \\
\hline Bahrain & 14 & 0 & 0 & 4 & 4 & 0.3 \\
\hline Estonia & 14 & 35 & 2.5 & 5 & 40 & 2.9 \\
\hline Finland & 13 & 213 & 16.4 & 76 & 289 & 22.2 \\
\hline Uganda & 13 & 0 & 0 & 58 & 58 & 4.5 \\
\hline Hungary & 12 & 90 & 7.5 & 27 & 117 & 9.6 \\
\hline Nigeria & 12 & 27 & 2.3 & 0 & 27 & 2.3 \\
\hline Trinidad & 12 & 0 & 0 & 3 & 3 & 0.25 \\
\hline New Zealand & 11 & 61 & 5.5 & 10 & 71 & 6.5 \\
\hline Qatar & 10 & 16 & 1.6 & 7 & 23 & 2.3 \\
\hline Romania & 10 & 56 & 5.6 & 1 & 57 & 5.7 \\
\hline Lithuania & 9 & 11 & 1.2 & 9 & 20 & 2.2 \\
\hline Croatia & 9 & 47 & 5.2 & 12 & 59 & 6.5 \\
\hline Slovenia & 8 & 36 & 4.5 & 4 & 40 & 5 \\
\hline Slovakia & 7 & 47 & 6.7 & 13 & 60 & 8.6 \\
\hline Switzerland & 7 & 283 & 40 & 60 & 343 & 49 \\
\hline Latvia & 6 & 113 & 18.8 & 1 & 114 & 19 \\
\hline Bulgaria & 6 & 29 & 4.8 & 3 & 32 & 5.3 \\
\hline Venezuala & 6 & 3 & 0.5 & 0 & 3 & 0.5 \\
\hline Ecuador & 6 & 2 & 0.3 & 12 & 14 & 2.3 \\
\hline Serbia & 5 & 14 & 2.8 & 8 & 22 & 4.4 \\
\hline Ireland & 5 & 227 & 45.4 & 7 & 234 & 46.8 \\
\hline
\end{tabular}

IAAF, International Association of Athletics Federation; NADO, National Anti-Doping Organisations; OOC, out-of-competition.

\section{OOC TESTS BY NADOS PER EA}

In table 1, the third column shows the total OOC tests done by each country's NADO. The total includes urine tests, blood tests for human growth hormone and blood for athlete biological passport. The figures quoted are based on WADA testing figures 2018 published in December 2019.

The rate of OOC testing by each NADO per EA (the fourth column) shows a very wide variation with some of the most successful countries doing relatively little testing.

\section{ROLE OF WORLD ATHLETICS IN ANTI-DOPING}

World Athletics (previously the International Association of Athletics Federation (IAAF)) stated in 2016 that 'the IAAF has been filling the gaps for too long through its International Testing Programme and that it should be able to rely on robust and relevant national anti-doping programmes proportional to the international success of the athletes and the forms of doping in the countries in question.'

Table 1 also shows the OOC tests done by the Athletics Integrity Unit of World Athletics in 2018 (the fifth column). This information was provided directly to the author, on request, by World Athletics. Perhaps World Athletics might review the distribution of their testing programme in the light of this study as countries like Germany and Finland appear to have quite robust NADO testing programmes.

\section{TESTING LEAGUE TABLE}

Table 2 shows the different rates of total OOC tests per EA for all countries with five or more EAs from the most tested to the least tested. While some of the most successful countries do comparatively little testing, it would be simplistic and misleading to suggest that a low level of OOC testing is the sole or the main reason why the country is successful in the first place. Factors such as natural talent, sporting facilities, coaching expertise, appropriate weather, training companions and good competition contribute to success in athletics.

\section{REGIONAL ANTI-DOPING ORGANISATIONS}

Regional Anti-Doping Organisations (RADOs) also contribute to OOC testing, and the work of three RADOs will be commented upon here.

Africa Zone V (geographically 12 countries in northeastern Africa, including Ethiopia and Kenya) reported only 4 OOC urine tests in 2018, thus making no significant difference to the overall testing rate for these high-profile countries. There were no OOC tests done by Africa Zone $\mathrm{V}$ on athletes from Kenya or Ethiopia.

Africa Zone I (consisting of Algeria, Libya, Mauritania, Morocco and Tunisia) contributed 238 OOC urine tests and 1 OOC blood test in 2018. The author has been unsuccessful in getting a breakdown of that figure per country. Taking the five countries together, the total OOC test, including NADOs, IAAF and RADO, amounts to 446 , giving an OOC test rate of 20.3 per EA.

This compares very favourably with the EU27, which has a total (NADO plus IAAF) test rate of 13.45 OOC tests per $\mathrm{EA}$. The equivalent figure for the UK is 9.5 and for the USA is 6.24 .

The RADO for Gulf States and Yemen contributed 7 OOC tests in 2018, giving a total OOC test figure of 138, of which the IAAF contributed 104. The test rate per EA for this region is 4.9 . 
Table 2 Out-of-competition (OOC) tests in athletics in 2018 per elite athlete ranked in descending order

\begin{tabular}{|c|c|}
\hline Country & Total OOC testing rate \\
\hline Switzerland & 49 \\
\hline Ireland & 46.8 \\
\hline Turkey & 32.3 \\
\hline China & 28.7 \\
\hline Germany & 23.5 \\
\hline Finland & 22.2 \\
\hline Spain & 21.3 \\
\hline Russia & 19.8 \\
\hline Latvia & 19 \\
\hline India & 15.5 \\
\hline Norway & 14.5 \\
\hline Italy & 13.8 \\
\hline Sweden & 11.8 \\
\hline Kenya & 11.1 \\
\hline France & 10.7 \\
\hline Morocco & 10.6 \\
\hline Ethiopia & 10.2 \\
\hline Belgium & 9.8 \\
\hline Hungary & 9.6 \\
\hline UK & 9.5 \\
\hline Ukraine & 9.4 \\
\hline Japan & 8.9 \\
\hline Czech Republic & 8.9 \\
\hline Netherlands & 8.7 \\
\hline Slovakia & 8.6 \\
\hline Portugal & 7.9 \\
\hline Canada & 7.5 \\
\hline Poland & 7.1 \\
\hline Australia & 6.9 \\
\hline New Zealand & 6.5 \\
\hline Croatia & 6.5 \\
\hline Belarus & 6.2 \\
\hline USA & 6.2 \\
\hline South Africa & 6.1 \\
\hline Romania & 5.7 \\
\hline Bulgaria & 5.3 \\
\hline Slovenia & 5 \\
\hline Uganda & 4.5 \\
\hline Jamaica & 4.4 \\
\hline Serbia & 4.4 \\
\hline Cuba & 3.1 \\
\hline Estonia & 2.9 \\
\hline Colombia & 2.6 \\
\hline Qatar & 2.3 \\
\hline Ecuador & 2.3 \\
\hline Nigeria & 2.3 \\
\hline Lithuania & 2.2 \\
\hline Greece & 1.9 \\
\hline Brazil & 1.4 \\
\hline Venezuala & 0.5 \\
\hline Bahrain & 0.3 \\
\hline Trinidad & 0.25 \\
\hline
\end{tabular}

\section{CONCLUSION}

There is a huge variation in the level of OOC testing worldwide with some of the most successful countries recording comparatively very low levels of testing.

All NADOs operate within budgetary constraints and cannot substantially increase their testing rate without a significant increase in their budgets. If WADA does take action to direct a prescribed level of testing, particularly OOC testing, then pressure will need to be applied to funders of NADOs, particularly at government level, in order for NADOs to comply with higher testing rates.

There is no reliable information on the level of use of PEDs in sport in different countries, and so no definitive conclusion can be drawn on the relation between testing frequency and the use of PEDs. What can be stated however is that generally the lower the level of testing, the lower is the number of positive tests for PEDs, to the point that if no tests are done, there will be no positive tests.

The information contained in these testing figures in vital in informing debate about the effectiveness of current anti-doping programmes. In the author's opinion, it would be premature to dismiss routine OOC testing as ineffective as, to date, a robust anti-doping programme has not yet been tried in many countries, including many countries that can afford to do it.

\section{Contributors $\mathrm{BC}$ is the sole author of this work.}

Funding The author has not declared a specific grant for this research from any funding agency in the public, commercial or not-for-profit sectors.

Competing interests None declared.

Provenance and peer review Not commissioned; externally peer reviewed. Data availability statement Data are available upon request.

Supplemental material This content has been supplied by the author(s). It has not been vetted by BMJ Publishing Group Limited (BMJ) and may not have been peerreviewed. Any opinions or recommendations discussed are solely those of the author(s) and are not endorsed by BMJ. BMJ disclaims all liability and responsibility arising from any reliance placed on the content. Where the content includes any translated material, BMJ does not warrant the accuracy and reliability of the translations (including but not limited to local regulations, clinical guidelines, terminology, drug names and drug dosages), and is not responsible for any error and/or omissions arising from translation and adaptation or otherwise.

Open access This is an open access article distributed in accordance with the Creative Commons Attribution Non Commercial (CC BY-NC 4.0) license, which permits others to distribute, remix, adapt, build upon this work non-commercially, and license their derivative works on different terms, provided the original work is properly cited, appropriate credit is given, any changes made indicated, and the use is non-commercial. See: http://creativecommons.org/licenses/by-nc/4.0/.

ORCID iD

Bill Cuddihy http://orcid.org/0000-0003-2986-0269

\section{REFERENCES}

1 Westmattelmann D, Dreiskämper D, Strauß B, et al. perception of the current anti-doping regime - a quantitative study among German top-level cyclists and track and field athletes. Front Psychol 2018:9:1-14.

2 Matthews P. Athletics 2019: the international track and field annual. York, UK: Sports Books Limited, 2019. 